\title{
Economic Growth in Nepal: Macroeconomic Determinants, Trends and Cross-Country Evidences
}

\author{
Luna Ghimire ${ }^{1}$, Ajay Kumar Shah², Ram Kumar Phuyal, 4, * \\ ${ }^{1}$ Ace Institute of Management (AIM), Pokhara University, Pokhara, Nepal \\ ${ }^{2}$ Ace Research Centre, Ace Institute of Management (AIM), Pokhara University, Pokhara, Nepal \\ ${ }^{3}$ Centre for Economic Development and Administration (CEDA), Tribhuvan University, Kirtipur, Nepal \\ ${ }^{4}$ National Planning Commission, Government of Nepal, Kathmandu, Nepal
}

Email address:

phuyal_ram5@yahoo.com (R. K. Phuyal)

${ }^{*}$ Corresponding author

\section{To cite this article:}

Luna Ghimire, Ajay Kumar Shah, Ram Kumar Phuyal. Economic Growth in Nepal: Macroeconomic Determinants, Trends and CrossCountry Evidences. Journal of World Economic Research. Vol. 9, No. 1, 2020, pp. 66-72. doi: 10.11648/j.jwer.20200901.20

Received: February 24, 2020; Accepted: April 20, 2020; Published: May 18, 2020

\begin{abstract}
Using time series data of the last twenty-seven years (1990 to 2016), this study tries to go in-depth regarding the relationship between macroeconomic variables and its impact on economic growth of Nepal. Further, this study also compares the economic growth of Nepal with six Asian countries such as Bangladesh, Bhutan, China, India, Pakistan and Sri Lanka. The study is based on secondary data which are extracted from a legitimate source of World Bank. The dependent variable of this study is Gross Domestic Product (GDP) growth (annual\%). To observe the GDP growth, some independent variables like exchange rate, export of goods and services, Foreign Direct Investment (FDI) net flow, Gross Fixed Capital Formation (GFCF), import of goods and services and inflation are chosen. Based on the variables, statistical tools such as multiple linear regression, Karl Pearson's correlation, and trend analysis are run. As per the result, exchange rate, GFCF, and import have a significant impact on the economic growth of Nepal while export, FDI, and inflation do not have a significant impact. Further, the cross-country evidence shows that Bangladesh and India have a significant positive GDP growth trend, while Bhutan and Sri Lanka have a positive GDP growth trend but do not have a significant growth. Also, China, Nepal, and Pakistan do not have a significant growth and their growth trend is negative. Based on the results and analysis it is suggested that a strong exchange rate leads low cost of production with cheap imports and also helps to control inflation due to low prices of foreign goods and services. In this context, the policymaker should initiate to make tight policies against the reduction of inflation in the country.
\end{abstract}

Keywords: Economic Growth, GDP, Exchange Rate, Export, FDI, GFCF, Import, and Inflation

\section{Introduction}

It is now widely accepted that a stable macroeconomic framework is necessary for maintaining sustainable economic growth. The concept of a stable macroeconomic framework means a macroeconomic policy environment that is conducive to growth. However, merely being limited to that framework may not be sufficient because the definition of framework goes beyond the stability of macroeconomic policy related variables to also include the criterion of policyrelated variables that are at levels conducive to growth.

Basically, the integration of the global economy along with the enrichment in communication technology has helped in enhancing the economic growth of any country. FDI, import, and export are the fundamental representation of this fact [1]. However, FDI inflows are only taken and outflows are excluded when we consider determinants of GDP. Likewise, imports are subtracted from exports when forming up GDP. When GDP is estimated at current prices, it exhibits nominal GDP, whereas real GDP is when the estimation is made at constant prices. Nominal GDP estimates are commonly used to determine the economic performance of a whole country or region, and to make international comparisons. Nominal GDP per capita does not, however, reflect differences in the 
cost of living and the inflation rates of the countries; therefore, using a basis of GDP per capita at purchasing power parity (PPP) is arguably more useful when comparing differences in living standards between different nations [2].

Moreover, a country's economic position depends on key macroeconomic variables that have the greatest influence on its growth. The economic growth represents the interactions of the important components of the economy and GDP is the major determinant of it. Indeed, economic growth and financial development are closely related. The interaction between them is crucial and has attracted great attention from researchers and policymakers. Financial institutions basically facilitate the transfer of funds from surplus units to deficit units and provide benefits for both the saving units and deficit units in the societies. This influences the growth rate of both the societies [3].

Meanwhile, the major research issue here is the impact that macroeconomic variables have on the economic growth of Nepal. The underlying determinants that influence economic growth of a country are quite vast and debatable. GDP is an indicator of economic growth as it gives an overall picture of the state of the economy. There has been a lot of studies around the world in terms of economic growth and variables influencing the growth. But not all researches are based on the same variables of the growth as growth is not bounded by specific variables. There are a lot of factors influencing it and it is fair enough to say that not all researches can include all the factors of economic growth. Besides this, their research objectives also differ as some research may consider variables at the macro level, while some may consider them at the micro level. In addition to this, comparative researches can be found mostly done in developing countries other than Nepal. When considering those researches about Nepal, they mainly concern about economic growth and financial development. Likewise, in spite of the fact that Nepal's economic growth rate is not that higher as compared to other developing countries, so far there has been only limited studies conducted considering the impact of macroeconomic variables in Nepalese economic growth. But the growth rate of Nepal cannot be ignored if a good economic position is to be maintained.

Thus, this study makes an attempt to answer two basic research questions- what impact do macroeconomic variables have in the economic growth of Nepal? And how is the trend of economic growth of six South Asian countries as compared to Nepal? Based on these questions, the major research objective of the study is to examine the relationship between macroeconomic variables and its impact on economic growth of Nepal. Along with this, this study also compares the economic growth rate of Nepal with six South Asian countries. Thus, the result obtained from this study provides an in-depth information to its readers. It provides an overview of GDP growth rate in Nepal. By this, readers can be aware of the current scenario of Nepal's economy.

\section{Literature Review}

There is extensive review on economic growth related to macroeconomic determinants, trends and cross-country globally. The strength of an economy can be assessed by analyzing the macroeconomic determinants, which are empirically tested. Various international studies suggest that these parameters vary from country to country and time to time [4]. Growth theories highlight the evolution and trends in economic thought that shaped the way economic growth is perceived [1]. GDP is one of the important determinants of a country's economic growth [5]. Further, it is expressed that developing county's GDP is confused and unbalanced, with regular and deep unconditional GDP falls and booms. Although GDP might seem a distant and abstract economic indicator, it is surprising how much it affects the decision making of policymakers and even individual consumers and by so, the whole economy. GDP information has a more important role than ever and today low growth figures might be seen by the public as bad performance [6].

Also, FDI is an important source of foreign currency for a state. FDI has a significant long-run impact on states' GDP. While no consensus has been reached on the relationship between FDI and growth, there is growing acceptance of the view that FDI correlates positively to growth. This view has been bolstered by recent research in the growth theory literature, which highlights the importance of improvements in technology, efficiency, and productivity [7]. Also, FDI is an important factor in economic growth. The reason for this is that investment is the dynamic element of GDP and therefore, FDI is the independent variable and GDP growth the dependent [8]. Similarly, investigation on FDI, and foreign aid impact on the regional economic growth of the developing countries of Africa, Latin America, and the Caribbean has found spatial interdependence is important in explaining economic growth, as growth in one country depends on the growth of its neighboring countries [9]. Another study pointed out the role of FDI and productivity progress in China's post-economic reform growth shows consistent results with some recent findings in other developing countries in that FDI exerted spillover effects and affected productivity growth of the recipients [10]. A high volume of exports, plentiful natural resources, longer life expectancy, and higher investment rates have positive impacts on the growth of per capita gross domestic product in developing countries [11].

Moreover, the relationship between growth rate of GDP and certain macroeconomic variables like domestic investment rate, domestic saving rate, inflation rate and trade openness in European countries and observed that domestic investment and saving rates are positively associated with GDP growth rate for each country taken as the sample [12]. Mbulawa in his study established the key drivers of economic growth to determine the causal relationship between economic growth and macroeconomic variables and found that FDI and inflation had a positive effect on economic growth. The outcome was unidirectional moving from economic growth to FDI and from gross fixed capital formation to GDP growth [13].

A study has shown that certain macroeconomic variables 
are more important than others in explaining short-term GDP growth [14]. Growth is negatively associated with inflation, large budget deficits, and distorted foreign exchange markets. Kormendi and Meguire's paper has presented post-war data and argued that the investment-to-income ratio has a major effect on economic growth [15]. Sarel in his found evidence of a significant structural break in the function that relates economic growth to inflation which is estimated to occur when the inflation rate is 8 percent [16]. Below that rate, inflation does not have any effect on growth or it may even have a slightly positive effect. AiNajjar in his study has revealed that economic growth was found to be positively related to gross domestic investment as a percentage of GDP and terms of trade, and negatively related to the inflation rate and total expenditure on health and education as a percentage of GDP [17].

Bassanini and Scarpetta suggest that high inflation is negatively associated with the accumulation of physical capital in the private sector and, through this channel, has a negative bearing on output. Moreover, a high variability of inflation affects GDP per capita, possibly because it leads to a shift in the composition of investment towards less risky but also lower return projects [18]. Economic growth measured by GDP means the increase in the growth rate of GDP, but what determines the increase of each component is very different. Public expenditure, capital formation, private or public investment, employment rates, exchange rates etc. have different impacts on economic growth and these determinants have different implications if the states are developed or not [1].

In the Asian context, a study stated that increasing stock of physical capital helps to contribute to growth in Pakistan while budget deficit is negatively related to both output growth variables [19]. Booming FDI in post-reform India is widely believed to promote economic growth [20]. In addition to other cross- country evidence, the impact of key macroeconomic factors on the economic growth of Bangladesh from the period of 1988 to 2012 argued that market capitalization, FDI, and real interest rate have an impact on economic growth in the long run, but in the short run, it does not have any predictable behavior [21].

Another study examines the impact of major economic variables-inflation rate, interest rate and exchange rate on economic growth of Pakistan and found that both the inflation rate and interest rate spread has a negative impact on Pakistan's economic growth while the exchange rate was found positively significant on the economy [22]. Yet, another research found that there was a significant effect of the inflation rate, interest rate and exchange rate on GDP of Pakistan. Inflation and interest rate had a negative impact on GDP while exchange rate possessed positive relation to GDP [23]. Considering the study of Nepal, the economic development strategies of Nepal and Bhutan and reveal that domestic capital has been a significant source of economic growth in the case of Nepal whereas foreign aid has not had any appreciable effect on growth. The empirical evidence confirms that financial development is the cause for economic growth in terms of short-term dynamics, while economic growth sustains financial development in the longrun [24]. Some studies for instance has shown for positive impact of FDI on economic growth while few others have shown negative impact or no impact at all on growth [25].

In case of Nepal, it has implemented extensive reforms during the early nineties to facilitate its integration with the global economy. However, the impact of these reforms on trade and economic growth has so far been weak and suggested that Nepal should find a way of translating its integration with the global economy into higher growth and sustainable development by carrying out complementary policies to enhance supply elasticity and offset some of the adverse outcomes by cooperative action in partnership with its South Asian neighbors [26]. However, today it is still not clear as to which factors are the principal drivers of economic growth within and among countries. Many governments do not know the key drivers of economic growth specific to their economies. The new literature on empirical growth research stresses the importance of how country-specific development plans and economic reforms can cause different equilibrium, or time paths, for economic growth of a country [27].

In light of the above researches, this research also tries to figure out whether Nepal's economic growth was good enough or not by trying to trace out the complex relationship between GDP and other macroeconomic variables influencing it. Considering the above-mentioned works of literature into account, this research analyzed the data of the past twenty-seven years taking dependent and independent variables into account. Moreover, GDP here was placed as a dependent variable and the impact of other independent variables (exchange rate, export, FDI, GFCF, import, and inflation) on GDP was studied. Also, cross-country evidence was considered to determine the result. Hence, all the abovecited pieces of literature assisted in conducting this research by acting as a reference to help better analyze the findings.

\section{Methodology}

\subsection{The Conceptual Model}

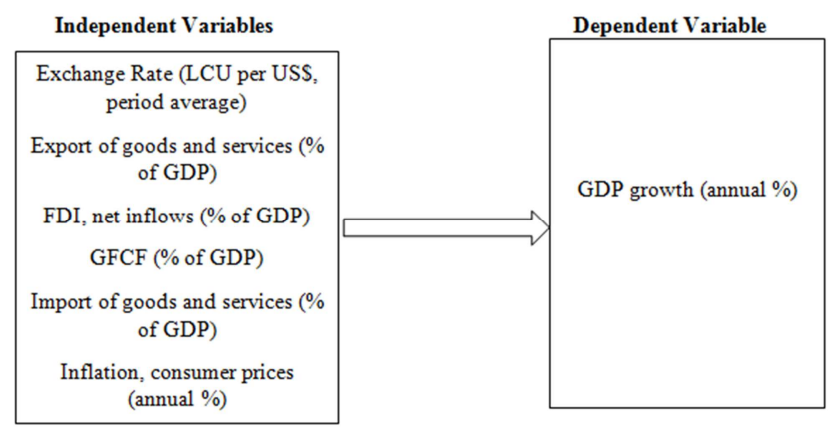

Figure 1. Conceptual Framework.

The dependent of this study is GDP growth (annual\%). This model is based on the research model of Chughtai, Malik, \& Aftab [22] and Upreti [11]. To observe the GDP 
growth, some independent variables like exchange rate, export of goods and services, FDI net flow, GFCF, import of goods and services and inflation were chosen. These variables are justifiable for this study as they are among the major determinants affecting a country's GDP growth. Moreover, when studying research works from different authors, most of them have also included these variables in their study. Representing them, my conceptual model is a wider array of essential variables. The details of variables are given as:

Exchange Rate on Local Currency Unit (LCU per US\$, period average): In this research, data on exchange rates quoted in values against the US dollar were taken. It is calculated as an annual average based on monthly averages (local currency units relative to the U.S. dollar).

Export of goods and services (\% of GDP): In this report, the export of goods and services were taken which were expressed as a percentage of GDP. It facilitates international trade and stimulates domestic economic activity by creating employment, production, and revenues.

FDI, net inflows (\% of GDP): In this report, data on FDI inflows as a percentage of GDP were only considered.

GFCF (\% of GDP): In this research, data from GFCF were expressed as a percentage of GDP. Statistically, it measures the value of acquisitions of new or existing fixed assets by the business sector, governments and pure households (excluding their unincorporated enterprises) fewer disposals of fixed assets. GFCF is a component of the expenditure on GDP, and thus shows something about how much of the new value added in the economy is invested rather than consumed.

Import of goods and services (\% of GDP): In this report, import of goods and services were taken which were expressed as a percentage of GDP. Basically, it is a good or service brought into one country from another. The higher the value of imports entering a country, compared to the value of exports, the more negative that the country's balance of trade becomes.

Inflation, consumer prices (annual\%): In this report, the annual percentage of consumer prices inflation was taken. When the general price level rises, each unit of currency buys fewer goods and services. Consequently, inflation also reflects erosion in the purchasing power of money- a loss of real value in the internal medium of exchange and unit of account within the economy.

Based on the variables, multiple regression models were used for data analysis in this research. It is presented below:

$$
Y_{1}=\beta_{0}+\beta_{1} X_{1}+\beta_{2} X_{2}+\beta_{3} X_{3}+\beta_{4} X_{4}+\beta_{5} X_{5}+\beta_{6} X_{6}
$$

Where,

$\mathrm{Y}_{1}=$ GDP growth (annual\%)

$\mathrm{X}_{1}=$ Exchange Rate (LCU per US\$, period average)

$\mathrm{X}_{2}=$ Export of goods and services ( $\%$ of GDP)

$\mathrm{X}_{3}=\mathrm{FDI}$, net inflows ( $\%$ of GDP)

$\mathrm{X}_{4}=$ Gross FCF ( $\%$ of GDP)

$\mathrm{X}_{5}=$ Import of goods and services ( $\%$ of GDP)

$\mathrm{X}_{6}=$ Inflation, consumer prices (annual\%)

\subsection{Data Source and Analysis Methods}

This study was based on secondary data which were extracted from a legitimate source of World Bank. From the website of World Bank, a section called 'data bank' was referred in order to extract data for the sample period of twenty-seven years i.e. from the year 1990 to 2016. The use of secondary data here was done because the quality of data was quite reliable as compared to primary data for analyzing the interrelationship between macro-economic variables and economic growth of Nepal. As data were extracted from the website of World Bank, these data were considered highly reliable. After the data collection from secondary sources, data were presented using MS-Excel and analysis were done using SPSS software where statistical tools like multiple linear regression, Karl Pearson's correlation, and trend analysis were run. Different tables and graphs were used to present the output of SPSS in the report.

\section{Result and Analysis}

\subsection{Pearson's Correlation Analysis}

The table 1 is the Pearson's correlation matrix which shows the correlation among different variables taken under this study for the sample period of 1990 to 2016 . However, the main motive of this research is to see if there is any relationship between the dependent variable GDP growth and other independent variables influencing it.

Table 1. Correlation Matrix of Key Variables.

\begin{tabular}{llllllll}
\hline & $\mathbf{X}_{\mathbf{1}}$ & $\mathbf{X}_{\mathbf{2}}$ & $\mathbf{X}_{\mathbf{3}}$ & $\mathbf{X}_{\mathbf{4}}$ & $\mathbf{X}_{\mathbf{5}}$ & $\mathbf{X}_{\mathbf{6}}$ & $\mathbf{X}_{\mathbf{7}}$ \\
\hline $\mathrm{X}_{1}$ & 1 & -0.377 & 0.135 & -0.051 & -0.313 & -0.086 & 0.151 \\
& & 0.052 & 0.503 & 0.801 & 0.112 & 0.669 & 0.452 \\
$\mathrm{X}_{2}$ & & 1 & -0.339 & 0.344 & $.697^{* *}$ & $.742^{* *}$ & -0.27 \\
& & & 0.084 & 0.079 & 0 & 0 & 0.173 \\
$\mathrm{X}_{3}$ & & & 1 & -0.255 & -0.221 & -0.022 & -0.376 \\
& & & & 0.199 & 0.269 & 0.914 & 0.054 \\
$\mathrm{X}_{4}$ & & & & 1 & 0.374 & $.506^{* *}$ & 0.116 \\
& & & & & 0.054 & 0.007 & 0.564 \\
$\mathrm{X}_{5}$ & & & & & 1 & $.836^{* *}$ & 0.047 \\
& & & & & & 0 & 0.814 \\
$\mathrm{X}_{6}$ & & & & & & 1 & -0.156 \\
& & & & & & & 0.437 \\
$\mathrm{X}_{7}$ & & & & & & & 1 \\
\hline
\end{tabular}

** Correlation is significant at the 0.01 level (2-tailed).

Where,

$\mathrm{X}_{1}=$ GDP growth (annual\%)

$\mathrm{X}_{2}=$ Exchange Rate (LCU per US\$ period average)

$\mathrm{X}_{3}=$ Export of goods and services ( $\%$ of GDP)

$\mathrm{X}_{4}=$ FDI net inflows ( $\%$ of GDP)

$\mathrm{X}_{5}=$ Gross FCF ( $\%$ of GDP)

$\mathrm{X}_{6}=$ Import of goods and services ( $\%$ of GDP)

$\mathrm{X}_{7}=$ Inflation, consumer prices (annual\%)

There is a significant relationship between exchange rate and GFCF, FDI inflows and Import, exchange rate and Import, and GFCF and Import. It means that the Exchange rate and GFCF, FDI inflows and Import, exchange rate and 
Import, and GFCF and Import of Nepal are correlated and changes in one results into positive change in another. The significant relationship between these two variables to each other suggests that a change in one factor results in a significant change in another factor.

There is no significant relationship between GDP growth and Exchange rate, export, FDI inflows, import and inflation. It means that GDP growth and the mentioned variables are correlated and changes in one results in a moderate positive change in another. Similarly, this study found no significant relationship between Exchange rate, Export, FDI inflows and Inflation. Also, this study found no significant relationship between Export, FDI, GFCF, Import and Inflation. Further, there is no significant relationship between FDI inflows, GFCF and Inflation; and between Import and Inflation.

\subsection{Regression Analysis}

In this research, the functional expression between the dependent variable GDP and independent variables of Nepal can be expressed as,

$$
\mathrm{Y}_{1}=\beta_{0}+\beta_{1} \mathrm{X}_{1}+\beta_{2} \mathrm{X}_{2}+\beta_{3} \mathrm{X}_{3}+\beta_{4} \mathrm{X}_{4}+\beta_{5} \mathrm{X}_{5}+\beta_{6} \mathrm{X}_{6}
$$

Where,

$\mathrm{Y}_{1}=$ GDP growth (annual\%)

$\mathrm{X}_{1}=$ Exchange Rate (LCU per US\$, period average)

$\mathrm{X}_{2}=$ Export of goods and services (\% of GDP)

$\mathrm{X}_{3}=\mathrm{FDI}$, net inflows ( $\%$ of GDP)

$\mathrm{X}_{4}=$ Gross FCF ( $\%$ of GDP)

$\mathrm{X}_{5}=$ Import of goods and services ( $\%$ of GDP)

$\mathrm{X}_{6}=$ Inflation, consumer prices (annual\%)

Table 2. Regression Analysis of GDP and Independent Variables of Nepal.

\begin{tabular}{llll}
\hline Independent variables & Beta Coefficient & t & Sig. \\
\hline (Constant) & 7.642 & & \\
Exchange Rate (LCU per US\$, period average) & -.064 & -2.132 & .046 \\
Exports of Goods and Services (\% of GDP) & -.092 & -1.205 & .242 \\
FDI, Net Inflows (\% of GDP) & -1.912 & -1.090 & .289 \\
Gross FCF (\% of GDP) & -.599 & -2.637 & .016 \\
Imports of Goods and Services (\% of GDP) & .467 & 3.119 & .005 \\
Inflation, Consumer Prices (annual\%) & .060 & .560 & .582 \\
F Value & 2.610 & & 1.644 \\
P Value & 0.049 & & \\
R Square & 0.439 & & 1.788 \\
\hline
\end{tabular}

The above table 2 shows that the $\mathrm{R}$ square is 0.439 which means that 0.439 percent variation on dependent variable i.e. GDP growth is described by the independent variables (Exchange rate, Export, FDI, GFCF, Import, and Inflation) taken under consideration in this study. The $\mathrm{F}$ value is 2.610 with a corresponding $\mathrm{P}$ value of 0.049 which is less than the level of significance $(\alpha)=0.05$ signifying that there is a significant relationship between GDP growth and other independent variables of the regression equation. Also, Variance Inflation Factor (VIF) of all the data is less than ten, suggesting that multi-collinearity issue is not severe for the independent factors taken under consideration.

The regression coefficient of the Exchange rate (R.s. /\$), GFCF and Import shows statistically significant relationship these variables with GDP growth rate. Further, regression coefficient of the Exchange rate (R.s. $/ \$$ ) is -0.064 indicates that one unit change in exchange Rates (R.s. /\$) leads to 0.064 percent negative change in GDP growth. The regression coefficient of GFCF (-0.599) revealed that one percent change in GFCF decreases GDP growth by $0.599 \%$. Similarly, regression coefficient of Import is 0.467 , which means that the one percent change in the Import leads to 0.467 percent positive change in GDP growth rate. All these three variables reject the null hypothesis.

In another case, the coefficient of Export is -0.092, FDI inflows is -1.912 and Inflation is 0.060 , which means that one percent change in Export, FDI inflows and Inflation leads to 0.092 percent and 1.912 percent negative change in GDP growth. However, one percent change in the Inflation leads to 0.060 percent positive change in GDP growth rate.
Since the corresponding $\mathrm{P}$ values of all three variables is more than the level of significance $(\alpha)=0.05$, we cannot reject the null hypothesis.

\subsection{Trend Analysis of South Asian Countries with Respect to Year}

Table 3. GDP Growth Rate of South Asian Countries Based on Sample Period of Twenty Seven Years.

\begin{tabular}{llll}
\hline Countries & Beta Coefficient & t & Sig. \\
\hline Bangladesh & 0.088 & 4.969 & 0.000 \\
Bhutan & 0.088 & 1.041 & 0.308 \\
China & -0.077 & -1.273 & 0.215 \\
India & 0.117 & 2.330 & 0.028 \\
Nepal & -0.061 & -1.538 & 0.137 \\
Pakistan & -0.006 & -0.125 & 0.901 \\
Sri Lanka & 0.032 & 0.639 & 0.529 \\
\hline
\end{tabular}

In the above table 3, the data are based on the sample period of 1990 to 2016. In the case of India and Bangladesh, for the sample period of 1990 to 2016, the Beta coefficient is 0.117 and 0.088 respectively which indicates that the annual GDP growth rate is statistically significant and positive. Hence, we can say that India and Bangladesh have significant and positive GDP growth. For the sample period of 1990 to 2016, the Beta coefficient of Bhutan and Sri Lanka is 0.088 and 0.032 which indicates that the annual GDP growth rate is positive. Despite, the growth of Bhutan and Sri Lanka are positive. But in both case the relationship has not statistically significant. However, for the country China, Nepal and Pakistan Beta coefficient is negative. It indicates for the 
respective countries the GDP growth is in decreasing trend. However, the value is not statistically significant. Therefore, there is no sufficient evident to claim that they have negative GDP growth rate.

Thus, it can be seen that from the sample period of 27 years, India has the highest and significant growth rate while China has the lowest growth rate which is not significant. Also, Bangladesh has a significant growth rate.

\section{Conclusion}

Better economic growth is the basic aim of every country and Nepal is no exception. The finding of correlation analysis suggests that there is a positive correlation between the dependent variable GDP growth and independent variablesexport and inflation. While GDP growth has a negative correlation with the exchange rate, FDI inflows, GFCF, and import. Similarly, as per the regression analysis exchange rate, GFCF and import have a significant impact on the economic growth of Nepal. On the other hand, export, FDI-net inflows, and inflation-consumer prices do not have a significant impact on the economic growth of Nepal. Thus, three independent variables have a significant relation with GDP growth which means that change in these independent variables have a greater impact on GDP and hence on economic growth of Nepal.

Further, the cross-country evidence shows that Bangladesh and India have a significant positive GDP growth trend, while Bhutan and Sri Lanka have a positive GDP growth trend but do not have a significant growth. Also, China, Nepal, and Pakistan do not have a significant growth and their growth trend is negative. When considering the first significant factor in contributing to the economic growth of Nepal, it has a pegged exchange rate regime with Indian currency which in turn is neither completely free-floating nor fixed, but is managed by the Reserve Bank of India through buying and selling other currencies.

Therefore, a steady and stable business climate for favorable trade and investments is difficult to create in such a scenario. In addition to this, as per the result, import also has a significant role towards the economic growth of the nation. However, it would not be fruitful for Nepal to rely more on imports. So, taking care of this result what can be done is that the government of Nepal should take serious steps to reduce import \& increase export by relying more on its own productions with absolute advantages than enjoying products from abroad. Also, agricultural productions can be enhanced as Nepal has a better potential in the agricultural sector which can contribute better to GDP growth. Similarly, GFCF accumulation can be achieved by an increment in investments, land improvements, plant and machinery purchases, the construction of roads, railways and so on. And, we can say that Nepal has significantly improved in this part. Meanwhile, the nation is in a move to build railway system with India and China, so this would add to GFCF accumulation. Likewise, this study suggests policymakers to make tight policies against the reduction of inflation in the country by better-implementing tools such as controlling the money supply in the market through open market operation, setting up the appropriate interest rate and setting of bank reserve requirement.

\section{Declaration}

The views, conclusions, and recommendations derived in this document are narratives concluded by the authors, based on facts and findings derived in this paper, which do not reflect the official views and perspectives of the organizations where the authors are associated now. This study was conducted when co-authors were associated with AIM, and corresponding author was at CEDA in early 2018.

\section{References}

[1] Boldeanu, F. T., \& Constanitnescu, L. (2015). The main determinants affecting economic growth. Bulletin of the Transilvania University of Braşov, 8 (2), 330-338.

[2] Gross Domestic Product. (2018, June 7). Retrieved from Wikipedia, the free encyclopedia: https://en.wikipedia.org/wiki/Gross_domestic_product

[3] Gautam, B. P. (2014, December). NRB Working PaperFinancial Development and Economic Growth in Nepal. Retrieved from Nepal Rastra Bank Website: https://nrb.org.np/red/publica.php?tp=working_papers\&\&vw= 1000

[4] Rajesh Sharma, P. K. (2018). Impact of Selected Macroeconomic Determinants on Economic Growth in India: An Empirical Study. Sage, 1-11.

[5] Kira, A. R. (2013). The Factors Affecting Gross Domestic Product (GDP) in Developing. European Journal of Business and Management, 148-158.

[6] Tjukanov, T. (2011). Gross Domestic Product as a Modernday Economic Indicator. Helsinki Metropolia University of Applied Sciences.

[7] Chasco, D. H.-J. (2016). Long-Run Deteminants of Economic Growth in South America. Journal of Applied Economics., 169-192.

[8] Villegas-Zermeño, C. E.-F. (2015). Foreign direct investment and gross domestic product growth. Procedia Economics and Finance, $198-207$.

[9] Nwaogu, U. G., \& Ryan, M. J. (2015, February). FDI, Foreign Aid, Remittance and Economic Growth in Developing Countries. Review of Development Economics, 19 (1), 100$115 . \quad$ Retrieved from http://onlinelibrary.wiley.com/doi/10.1111/rode.12130/full

[10] Tuan, C., Ng, L. F., \& Zhao, B. (2009). China's posteconomic reform growth: The role of FDI and productivity progress. Journal of Asian Economics, 280-293.

[11] Upreti, P. (2015). Factors Affecting Economic Growth in Developing Countries. Major Themes in Economics.

[12] Betyák, O. (2012). An Econometric Analysis of Determinants of Economic Growth in Crisis Countries of European Union. Gazimağusa, North Cyprus: Eastern Mediterranean University. 
[13] Mbulawa, S. (2015). Effect of Macroeconomic Variables on Economic Growth in Botswana. Journal of Economics and Sustainable Development, 68-77.

[14] Cunningham, N. (2008). The Effects of Macroeconomic Factors on Economic Growth Within the Former Soviet Union. Stillwater, Oklahoma State.

[15] Kormendi, R. C., \& Meguire, P. G. (1985). Macroeconomic Determinants of Growth: Cross-Country Evidence. Journal of Monetary Economics, 141-163.

[16] Sarel, M. (1996). NonlinearE ffectosf Inflation on EconomicG rowth. Staff Papers (International Monetary Fund), Vol. 43 (No. 1 ), 199-215.

[17] Fouad K. AINajjar. (2002). Economic Freedom and Macroeconomic Determinants of Economic Growth:. Review of Accounting and Finance, 1 (3 ), 74 - 84.

[18] Bassanini, A., \& Scarpetta, S. (2001). The Driving Forces of Economic Growth: Panel Data Evidence for the OECD Countries. OECD Economic Studies, 9-55.

[19] Iqbal, Z., \& Zahid, G. M. (1998). Macroeconomic Determinants of Economic Growth in Pakistan. The Pakistan Development Review, 37 (2), 125-148.

[20] Chakraborty, C., \& Nunnenkamp, P. (2008). Economic Reforms, FDI, and Economic Growth in India: A Sector Level Analysis. World Development, Vol. 36 (No. 7), 1192-1212.
[21] Ali, M. A., Saifullah, M. K., \& Kari, F. B. (2015). The Impact of key Macroeconomic factors on Economic Growth of Bangladesh: A VAR Co-integration Analysis. International Journal of Management Excellence, 667-673.

[22] Chughtai, M. W., Malik, M. W., \& Aftab, R. (2015). Impact of Major Economic Variables on Economic Growth of Pakistan. ACTA Universitatis Danubius, 11 (2), 94-106.

[23] Hussain, A., Sabir, H. M., \& Kashif, M. M. (2016, June). Impact of Macroeconomic Variables on GDP: Evidence from Pakistan. European Journal of Business and Innovation Research, 4 (3), 38-52.

[24] Dhakal, D., Pradhan, G., \& Upadhyaya, K. P. (2009). Nepal and Bhutan: economic growth in two Shangri-Las. International Journal of Social Economics, 36 (1/2), 124 - 137.

[25] Phuyal, R. K. and Sunuwar, S. (2018). A Sectoral Analysis of Foreign Direct Investment on Economic Growth of Nepal. Journal of Business and Social Sciences Research, 3 (1), 1-12.

[26] Karmacharya, B. K. (2001, March 1). Economic Reforms in Nepal and their Implications for Trade, Economic Growth, Inequality and Poverty. South Asia Economic Journal, 2: 1, 87-103. Retrieved from BookSC: http://booksc.org/book/40487812/7f8078.

[27] Themba, G. Chirwa, N. M. (2016). Macroeconomic Determinants of Economic Growth: A Review of International Literature. South East European Journal of Economics and Business, 33-47. 